\title{
Ambilight alternatív megvilágítási technika Arduino által vezérelve \& screen capturing alkalmazásfejlesztés DirectX API felhasználásával
}

\author{
Tallódi László \\ Informatika Kar \\ Debreceni Egyetem, Müszaki Kar \\ Debrecen, Magyarország \\ laszlo.tallodi91@gmail.com
}

\author{
Erdei Timotei István \\ Mechatronikai Tanszék \\ Debreceni Egyetem, Müszaki Kar \\ Debrecen, Magyarország \\ timoteierdei@eng.unideb.hu
}

\begin{abstract}
Absztrakt-2004-ben, Philips által kifejlesztett Ambilight televíziók megjelenése nem hozott átütő sikert. 2010-ig mindösszesen négymillió ilyen tévét tudtak értékesíteni. A 3D technológiához hasonlóan az Ambilight szerü megvilágítási technológiák is igen megosztóaknak bizonyultak [1]. Projektemben egy Ambilight szerü, saját megvilágítási technika került megvalósításra, amihez az inspirációt az Ambilight technológia adta. A cél, hogy asztali számítógépes rendszereken is könnyen alkalmazható legyen és stabil-megbízható müködést lehessen vele elérni, aminek fö platformja Windows operációs rendszer. A projekt megvalósítása során megismerésre került a DirectX API által biztosított, úgynevezett „screen capturing” technológia, valamint az Arduino és intelligens, LED-enként vezérelhető LED-szalag programozási ismerete is.
\end{abstract}

Kulcsszavak-Arduino; Ambilight; Windows; DirectX; FastLED; Screen Capturing

\section{BEVEZETŐ}

A különböző eszközök és azok alkalmazása az oktatásban, illetve fejlesztési célból, komoly szakaértelmet kíván. A Debreceni Egyetem, Épületmechatronikai Kutatóközpontjában a jelenkor technológiái találhatóak meg, melyekkel új, innovatív rendszereket tervezünk [11][12].

$\mathrm{Az}$ Ericcson cég által végzett, éves TV és médiahasználatról szóló jelentése (ConsumerLab TV \& Media Report) [2] alapján 2010-2016-os időszakban a tradicionális TV nézés mértéke folyamatosan csökkent. A trendek változásával egyre több időt töltünk úgynevezett Video On Demand (röviden VoD) szolgáltatások használatával, amellyel a lineáris TV adások nem tudnak versenyezni.

Mindemellett az Ambilight-tal felszerelt TV készülékek sikerének elmaradása részben indokolható a pluszszolgáltatással járó magasabb árral [1]. A projekt tervezése során így törekedtem annak minél kisebb mértékü anyagi teherrel járó megvalósítására.

Az Ambilight jellegű megvilágítási technológia lényege a képernyőn megjelenő képből (általában a kijelző kávájának vízszintes és függőleges oldalainak mentén) mintavételezési pontokon színképet elemez és az a káva hátulján lévő LED lemásolja, ezáltal tágítja ki a néző képi érzékelését. Ehhez szükség van egy vezérlő egységre is.

Erre a szerep betöltésére egy Arduino board lett kiválasztva. Az Arduino a világ egyik vezető Open-Source platformja, amely magába foglalja mind a szoftveres fejlesztőkörnyezetét (IDE), mind pedig a hardvert. Segítségével a felhasználók müködő elektronikai prototípusokat tudnak létrehozni, akár önállóan működő, akár számítógép által vezérelve. A cég számos szoftveres és hardveres eszközt kínál. Az első Arduino eszközt 2005-ben mutatták be. Az Arduino típusok két nagy csoportra oszthatók. A fö fejlesztő paneleket „Board” névvel illetik, míg a bővítő lapok elnevezése: „Shield”. Az évek alatt több különböző modell jelent meg, ezek közös jellemzője, hogy Atmel mikrovezérlöket alkalmaznak és a programozási nyelvük azonos [3].

\section{TERVEZÉSI SZEMPONTOK}

A tervezés legfontosabb szempontja, annak a technológia eljárásnak a megtalálása és használatának beépítése, amellyel az intelligens LED-ek vezérlése legalább olyan kis válaszidővel valósuljon meg, amely még nem zavaró az emberi szem számára. A projekt során további szempont volt, hogy a LED szalag és vezérlésének elhelyezése, úgy valósuljon meg, hogy minél kisebb helyet foglaljon, és ne zavarja a monitor későbbi fali konzolra történő telepítését se [13].

A Windows operációs rendszeren futó szoftver tekintetében pedig, hogy olyan kommunikációs port kerüljön használatra, amely minden számítógépen megtalálható, így nem szükséges módosítás a program alap müködését tekintve.

A számítógép monitorjával szemben ülve magát a vezérelt fényforrás közvetlen nem látható ezért szükség van egy olyan fényforrásra, amely képes elegendő fényt kibocsájtani úgy, hogy a monitor mögött elhelyezett elég nagy felületü tárgyról (pl.: fal) visszaverődő fény ne is domináljon, de ne is legyen lényegesen kisebb erejü, mint maga a monitor által 
kibocsájtott fény. Természetesen a fényforrás vezérlését is meg kell oldani úgy, hogy a vezérlö jelet ne kelljen ismételni az adott monitor hátulján elhelyezett, viszonylagos nagyobb mennyiségü fényforrás esetében sem [14]. A tervezés során pozitív jelentőségü szempont, hogy könnyen felszerelhető legyen.

\section{LÉTREHOZOTT RENDSZER FELÉPÍTÉSE}

Egyszerűsített müködését illetően az Ambilight három részegység együttmüködésével történik. Fordított sorrendben tekintve szükség van egy fényforrásra, amely jelen esetben egy olyan LED-szalagot jelent, amely képes RGB szín keverésére, könnyen telepíthető a monitor hátoldalán lévő borításra, és vezérlése megoldható Arduino felhasználásával.

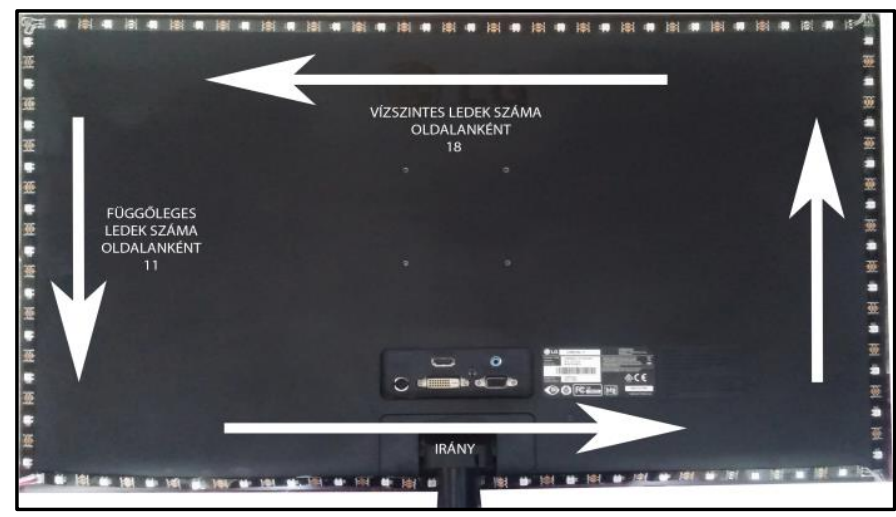

1. ábra: LED-szalag elhelyezési iránya, száma

A LED-szalag pontosan WS2812B típusú, úgynevezett intelligens LED (Light Emitting Diode) szalag került kiválasztásra. amelyen $5 \times 5$ mm-es 5050-es SMD RGB LED egybeépítve található a LED vezérlő IC-jével. Emellett a LED-szalag sürüsége $30 \mathrm{LED} /$ méter [4].

1. TÁBLÁZAT WS2812 FONTOSABB PARAMÉTEREI

\begin{tabular}{|c|c|c|c|}
\hline Paraméter & Jel & Határérték & Egység \\
\hline Tápfeszültség (vezérlö) & VCC & $+6,0-7,0$ & $\mathrm{~V}$ \\
\hline Tápfeszültség (LED) & VDD & $+6,0-7,0$ & $\mathrm{~V}$ \\
\hline Vezérlö bemeneti jelszint & DI & $-0,5-$ VDD $+0,5$ & $\mathrm{~V}$ \\
\hline Áramfelvétel (LED-enként / szín) & $\mathrm{I}$ & $0-20$ & $\mathrm{~mA}$ \\
\hline Adatsebesség & - & 800 & $\mathrm{kbps}$ \\
\hline
\end{tabular}

$\mathrm{Az}$ 1-es ábrán látható monitor méreteiből adódóan vízszintes oldalak mentén $2 \times 18 \mathrm{db}$, míg a függőleges oldalak mentén $2 \times 11 \mathrm{db}$ LED került elhelyezésre. Ezeket összeadva következik, hogy 58 db LED vezérlését kell megoldani.

$\mathrm{Az}$ 1.-es táblázat adataiból látható, hogy egy LED energia felhasználása RGB színekkel számolva összesen $60 \mathrm{~mA}$ teljes fényerősségen. A fentiekből adódóan a maximális energiafelhasználást a következő táblázat taglalja.

2. TÁBLÁZAT ENERGIAFELHASZNÁLÁS

\begin{tabular}{|c|c|c|}
\hline & Érték & Egység \\
\hline LED-ek száma & 58 & $\mathrm{db}$ \\
\hline $\begin{array}{c}\text { Áramfelvétel (Összes LED-et } \\
\text { tekintve) }\end{array}$ & 3480 & $\mathrm{~mA}$ \\
\hline Áramfelvétel (Mikrokontroller) & 50 & $\mathrm{~mA}$ \\
\hline
\end{tabular}

Áramfelvétel (összesen)

3530 $\mathrm{mA}$

A LED-szalag energiafelhasználását egy külső, 5V-os adapterrel került megvalósításra, míg a Nano USB porton kapja a müködéséhez szükséges feszültséget.

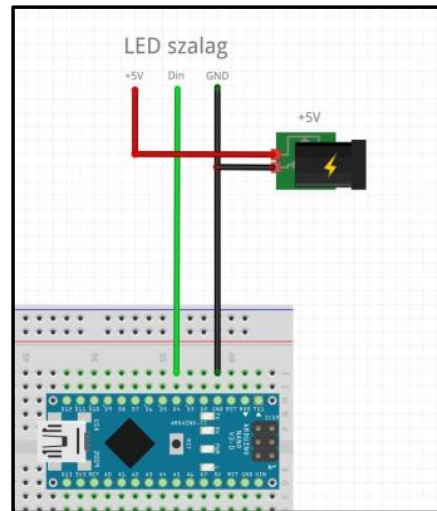

2. ábra: LED-szalag és Ardunio Nano összekötése

Második nagyobb részegység a LED-szalagot vezérlő mikrokontroller. Erre a feladatra egy Arduino Nano (továbbiakban Nano) lett kiválasztva, amely tartalmaz egy ATmega328-as (16MHz-es) mikrokontrollert, valamint Micro USB-n keresztül programozható. Méretéből $(18 \times 45 \mathrm{~mm})$ adódóan ideális választás a tervezési szempontok részben leírtak alapján [5].

\section{ARDUINO NANO PROGRAMOZÁSA}

A Nano programozása az Arduino ingyenesen elérhető (1.6.12 verziószámú) IDE-jében történt [6]. Az Arduino programozása egy egyszerüsített $\mathrm{C}$ nyelven történik. Nem feltétlenül szükséges érteni a mikrokontroller müködési elvét, elég az IDE menüpontjai között kiválasztani az alappanel fajtáját és az arra beépített mikrokontroller típusát. A programozáshoz felhasználásra került egy harmadik forrásból származó könyvtár: FastLed, amely támogatja a WS2812B lapkakészletét [7].

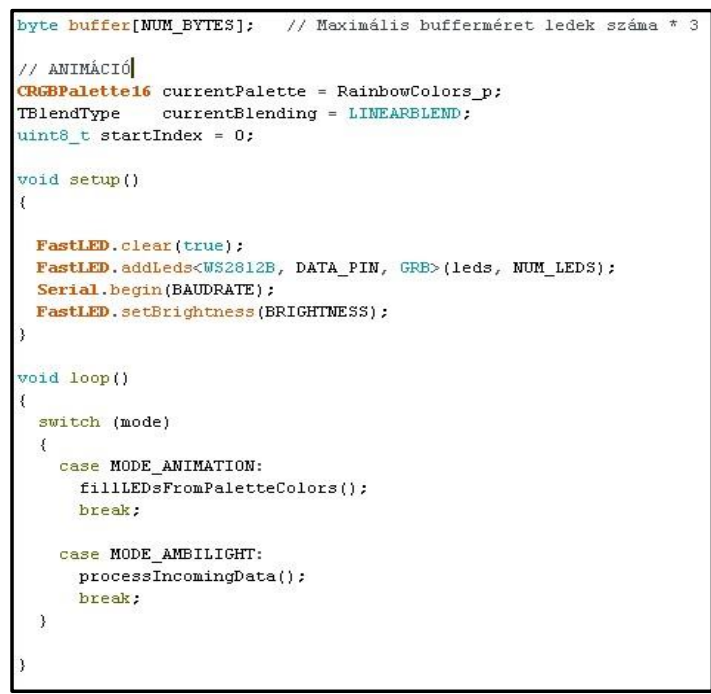

3. ábra: Részlet a Nano-n futó program forráskódjából 


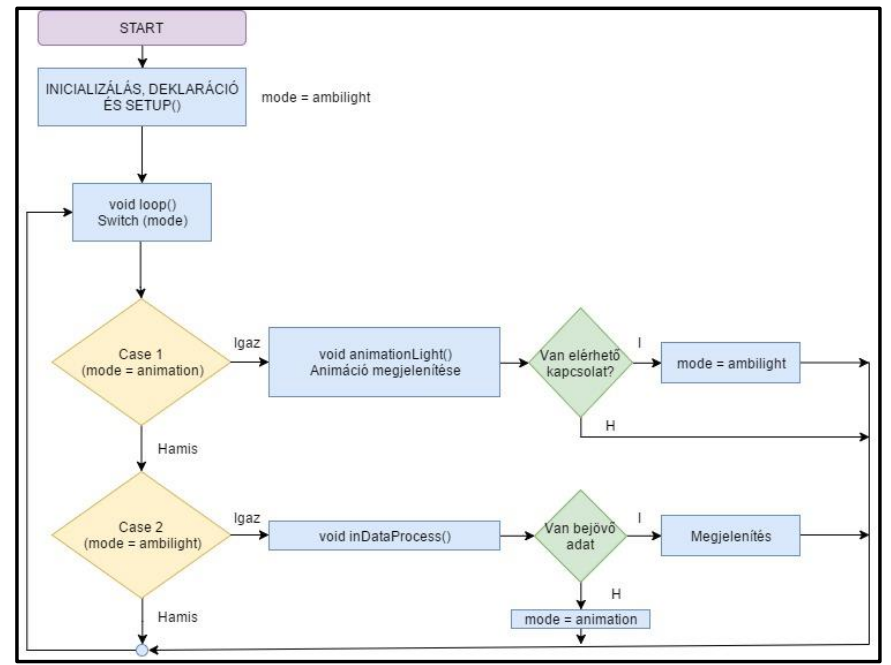

4. ábra: Részlet a Nano-n futó program forráskódjából

A 4. ábrában látható, hogy kettő értéket vehet fel a „mode” nevü változó. Ez a későbbi tesztelés elősegítésére került bele. Ha a program a Nano bemenetén nem érzékel jelet vagy bejövő adatot átvált egy úgynevezett animációs módra (a LED-szalagon körülhalad egy szivárványszín), így kizárva, hogy nem a Nano-n futó programmal, energiaellátással van probléma.

\section{WINDOWS OPERÁCIÓS RENDSZEREN FUTÓ „SCREEN CAPTURING” ALKALMAZÁS FELÉPÍTÉSE}

Többféle technika ismert a képernyő beolvasására Windows Operációs rendszer alatt. Ezek közül a két legismertebb a GDI és a DirectX API-t felhasználó technika. Ez előbbi a képernyőt egy ablaknak tekinti, és erről az ablakról pillanatképeket készít. Hátránya, hogy a folyamat rendkívül megterhelő a processzor számára. A DirectX alapú alkalmazás tartalmaz egy puffer-t, amely tárolja az alkalmazás videó memóriájában található tartalmat, ez az úgynevezett „,back buffer”. Ezen kívül van megtalálható egy „front buffer” is, amely a képernyőről tartalmaz információt. A ,front buffer"-t felhasználva hozzáférhetünk a különböző Windows operációs rendszeren futó alkalmazások ablakának tartalmához [8].

A screencapturing alkalmazást a Microsoft Visual Studio Community 2015 4.6.01055-ös verziójában lett megvalósítva Microsoft Windows 10 Operációs rendszer neve Microsoft Windows 10 Enterprise N 2015 operációs rendszer alatt [9]. Továbbá felhasználásra került a SlimDX nevü, ingyenes, nyílt forráskódú keretrendszer, elősegítve a könnyebb, .NET-en alapuló, DirectX API-t használó alkalmazások írását [10]. A program C\# nyelven íródott és több osztályt tartalmaz. Külön osztály kezeli a mintavételezési pontok beállítását és külön osztály kezeli például az adatok továbbítását a kommunikációs porton. A program kinézetét a Visual Studioban található Form segítésével került megvalósításra. Felépítése egyszerünek tekinthető. A müködéshez elengedhetetlen paraméterek megadásán kívül lehetőség van extra funkcióként arra, hogy a program indítása után egyből tálcára rakva induljon el, illetve a későbbi újra felhasználás érdekében megvalósításra került az $\mathrm{X}$ és $\mathrm{Y}$ tengely mentén történő tükrözés lehetőségének bekapcsolása.

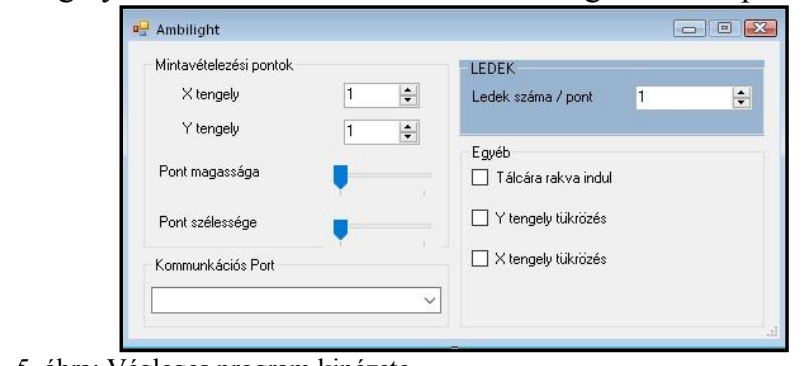

5. ábra: Végleges program kinézete

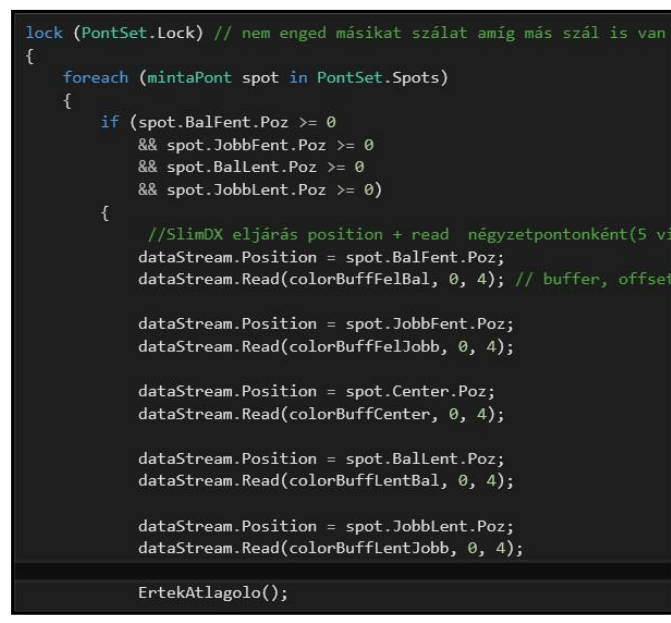

6. ábra: Részlet a forráskódból

A program esetében a mintavételezési eljárása a következőképpen történik: A program elindítása után megadható, hogy hány pontról történjen a mintavételezés. A kívánt hatás érdekében ennek meg kell egyeznie a monitor hátulján felhelyezett LED-ek darabszámával. X tengely jelöli a vízszintest, míg az Y a függőleges tengelyt jelenti a káva szélén.

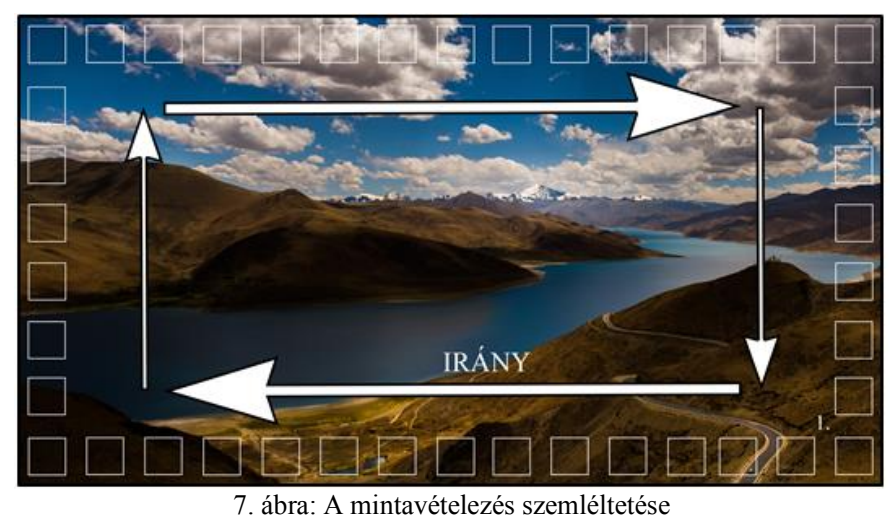

A 7. ábrán szemléltetésre került az úgynevezett négyzet alapú mintavételezési pontok elhelyezkedése. Ebben az esetben 15 vízszintes és 8 függőleges négyzet alapján történik az eljárás. A LED-szalag felhelyezési irányát 
figyelembe véve az első négyzetből (7. ábra jobb alsó sarkában lévő négyzet) lekérésre kerül 5, a 8. ábrán látható pozícióban lévő mintavételezési helyen (bal felső, jobb felső, középső, bal alsó, jobb alsó) lévő pixel ARGB szerinti színparamétere.

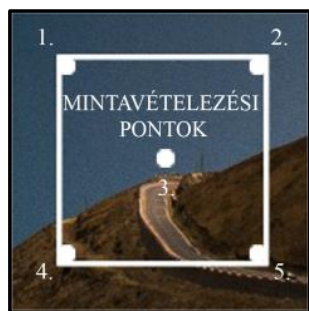

8. ábra: A négyzetben történő mintavételezési eljárás elnagyolt illusztrálása

Ez 4 darab paramétert (alpha, red, green, blue) jelenti, ahol az alpha az áttetszőséget jelenti. Ezután ezek átlagolása történik, majd tárolásra kerül, mint az osztálya egy objektuma. $\mathrm{Az}$ összes négyzeten belül megtörténik a mintavételezési eljárás, majd egy külön osztály, amely a soros porton csatlakozott Nano-val való kapcsolattartásért felel, ezen az objektumok paraméterét a kimenő bufferbe eltárolja, majd a megadott és sikeresen csatlakozott kommunikációs porton továbbításra kerül.

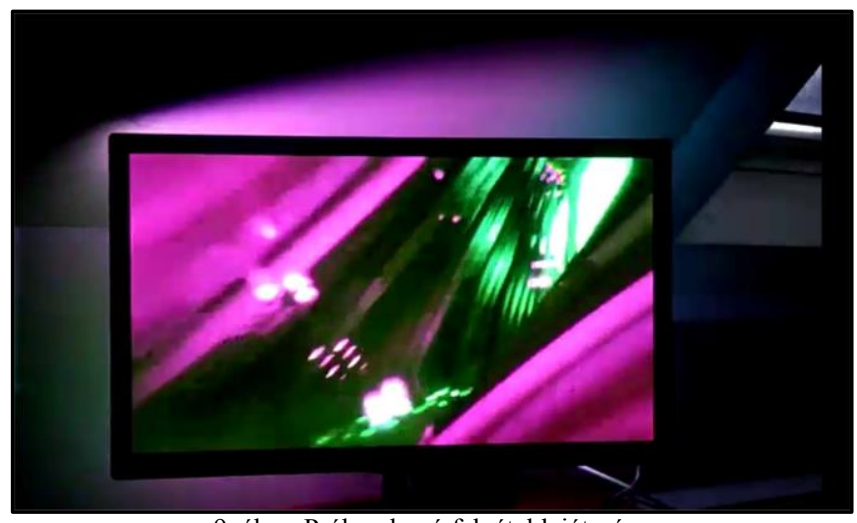

9. ábra: Próba, demó felvétel lejátszása

\section{VI. ÖSSZEGZÉS}

A projekt megvalósítása során egy müködő Ambilight szerü megvilágítási rendszer került megvalósításra asztali számítógépes környezetben. Szubjektív teszteléssel megállapítható, hogy eltekintve néhány feltáratlan színkeverési, illetve a vélhetően a vezérlés késéséből fakadó hibát, az asztali számítógépes Ambilight szerü kialakítás élvezhetőbbé teszi mind a számítógépes játékot, mind pedig a filmnézést, azáltal, hogy jelentősen kitágítja a monitor képének érzékelését.

\section{KÖSZÖNETNYILVÁNÍTÁS}

Köszönet illeti a Debreceni Egyetem Mechatronikai Tanszékének oktatóját a rendelkezésre bocsátott segítségért.

A publikáció elkészítését az EFOP-3.6.1-16-2016-00022 számú projekt támogatta. A projekt az Európai Unió támogatásával, az Európai Szociális Alap társfinanszírozásával valósult meg

\section{HIVATKOZÁSOK}

[1] Elefant, (2017, May 20). [Online]. Avalable: https://prohardver.hu/tudastar/ambilight.html

[2] Ericsson Consumerlab, (2017, May 20). [Online]. Avalable: https://www.ericsson.com/assets/local/networkedsociety/consumerlab/reports/tv-and-media-2016.pdf

[3] Málna PC, (2017, May 20). [Online]. Avalable: https://malnapc.hu/arduino/az-arduino-platform/

[4] Worldsemi WS2812 manual, (2017, May 20). [Online]. Available: http://www.seeedstudio.com/document/pdf/WS2812B\%20Datasheet.pdf

[5] Arduino, (2017, May 20). [Online]. Available: https://www.arduino.cc/en/Main/ArduinoBoardNano

[6] Arduino, (2017, May 17). [Online]. Available: https://www.arduino.cc/en/Main/Software

[7] Daniel Garcia (2017, May 21). [Online]. Available: https://github.com/FastLED/FastLED/wiki/Chipset-reference

[8] Gopalakrishna Palem, (2017, May 21). [Online]. Available: https://www.codeproject.com/Articles/5051/Various-methods-forcapturing-the-screen

[9] Microsoft (2017, May 05). [Online]. Available: https://www.visualstudio.com/downloads/

[10] SlimDX (2017, May 22). [Online]. Available: https://slimdx.org/index.php

[11] Mizik S, Baranyi P, Korondi P, Sugiyama M, „Virtual Training of Vector Function based Guiding Styles" Buletinul stiintific al universitatii politehnica din timisoara romania seria automatica si calculatorae / scientific bulletin of politechnica university of timisoara transactions on automatic control and computer science.

[12] Ohashi Toshiyuki, Szemes Peter, Korondi Peter, Hashimoto Hideki, „Nonlinear disturbance compensation for haptic device," IEEE International Symposium on Industrial Electronics. Konferencia helye, ideje: Bled, Szlovénia, 1999.07.12-1999.07.15. Abu Dhabi: pp. 304-309.

[13] T. I. Erdei, Zs. Molnár, N. C. Obinna, G. Husi, „Surveillance and Security System in the Building Mechatronics Research Center," Electrical Engineering and Mechatronics Conference EEMC'16 - 7th18th-19th March, 2016.

[14] T. I. Erdei, Zs. Molnár, N. C. Obinna, G. Husi, „Térfigyelő rendszer kialakítása az épületmechatronikai kutatóközpontban," MTEK MR Engineering Science in the North Eastern Region of Hungary - 25. May2016 